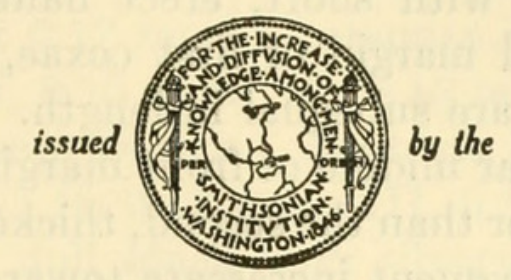

SMITHSONIAN INSTITUTION

U. S. NATIONAL MUSEUM

\title{
NEOTROPICAL MIRIDAE, LXV: NEW GENERA AND SPECIES OF BUGS OF THE TRIBE TERMATOPHYL- INI (HEMIPTERA: DERAEOCORINAE)
}

\section{By José C. M. Carvalho ${ }^{1}$}

Through the courtesy of Dr. Reece I. Sailer I was able to study some specimens of mirids in the collection of the U. S. National Museum, among which were the new genera and species of Termatophylini described in this paper.

The Termatophylini, recently brought within the Miridae as a tribe of Deraeocorinae (Carvalho, Anais Acad. Brasileira Cienc., vol. 24, pt. 1, p. 31,1952 ) were represented in the Neotropical region only by the genus Termatophylidea Reuter and Poppius (Öfv. Finska Vet.Soc. Förh., vol. 54A, pt. 1, p. 4, 1912). Two new genera and four new species are added here.

\section{Termatophyloides, new genus}

Deraeocorinae, Termatophylini. General aspect small, elongate, ovoid with head drawn to a point apically; smooth, densely, long and erected pilose.

1 Museu Nacional, Rio de Janeiro, Brazil; John Simon Guggenheim Memorial Fellow, 1953. Additional help granted by the Brazilian National Research Council. 
Head almost conical in shape, about as long as wide, eyes elongate, internal margins divergent anteriorly, slightly removed from pronotum; seen from the side almost touching basal segment of antennae, reaching the gula below, upper margin of eye slightly below upper margin of head, beset with short, erect hairs. Rostrum reaching approximately to apical margin of first coxae, first segment shorter than the others, which are subequal in length.

Antennae inserted near middle of front margin of eye, first segment about three times shorter than the second, thicker than the remaining, shortly pilose, second segment incrassate towards the apex, at widest portion subequal to first, third and fourth slender, longer than the first, pilose; first segment attaining only the apex of clypeus.

Pronotum with two distinct, transversally impressed grooves minutely punctate at bottom (punctures only visible with high magnification), imparting trilobed appearance to pronotum; the middle lobe bisected longitudinally by a similarly impressed furrow, collar wide, convex, and prominent, disc smooth with very long, semierect setiform pubescence, lateral margins almost straight, roundish posteriorly, almost carinate behind collar, hind margin broadly rounded; mesoscutum covered, scutellum flat with pointed apex.

Hemielytra smooth with pubescence similar to that of pronotum, clavus with a line of punctures along claval vein, brachial vein scarcely attaining apex of clavus, embolium almost evanescent on apical third, linear and slightly incrassate basally, cuneus declivous, about as long as wide at base, cuneal fracture well marked with distinct incisure, external margin noticeably emarginate near incisure; membrane with one areola, the vein rather wide and noticeably thickened with a slight fold along apical third of inner margin of cuneus.

Underside distinctly more shining, abdomen becoming prominently pilose towards the apex, peritreme large and pruinose; legs of moderate length, femora incrassate, covered by short pubescence, hind pair with two or three long setae about as long as width of femur arising from a pruinose area on apical lower third; tibiae without spines, finely pubescent, the hairs arranged in rows; tarsi with two basal segments about equal in length, together longer than the third, claws very small with a blunt basal lobe, of the Deraeocorinae type.

Type of genus: Termatophyloides pilosulus, new species.

This genus differs from Termatophylum Reuter, 1884, in the very long and semierect setiform pubescence and the characteristic transverse punctate furrow of the pronotum. 


\section{Termatophyloides pilosulus, new species}

Figure 123, $a, d, g$

Characterized by its color and dimensions.

Female: Length $2.1 \mathrm{~mm}$., width $0.99 \mathrm{~mm}$. Head length $0.35 \mathrm{~mm}$., width $0.33 \mathrm{~mm}$., vertex $0.17 \mathrm{~mm}$. Antennae segment I length 0.12 mm.; II, $0.21 \mathrm{~mm}$; III, $0.16 \mathrm{~mm}$.; IV, $0.18 \mathrm{~mm}$. Pronotum length $0.49 \mathrm{~mm}$., width at base $0.78 \mathrm{~mm}$. Rostrum length $0.63 \mathrm{~mm}$., segment I length $0.10 \mathrm{~mm}$; II, $0.17 \mathrm{~mm}$; III, $0.17 \mathrm{~mm}$.; IV, $0.18 \mathrm{~mm}$.

Color: General color dull black with silvery pubescence; apex of head subrufescent, basal segment of antennae fuscous, apex of third segment and apical four-fifths of fourth segment reddish, otherwise yellow, eyes rufescent, membrane brown; underside darkish to castaneous; femora and tibiae black, tarsi black except for basal segment which is yellowish.

Morphological characters: As given for the genus.

Male: Unknown.

Holotype: Female, Tamazunchale, San Luis Potosí, México, on orchids, Dec. 30, 1948, "Insp. Leary, coll., Laredo, Tex., 49529," USNM 61946.

Paratype: Female, Guatemala, on dried leaves with stalk of bananas, "Brownsville [Tex.], No. 53658 Lot. 433570," Apr. 10, 1943. One nymph with same data.

\section{Termatophylella, new genus}

Deraeocorinae, Termatophylini. Genus of small size, very shortly and adpressedly pilose, body ovoid, compact.

Head inclined, pointed, vertex faintly sulcate longitudinally, carinate; eyes roundish, small, orbita divergent towards the clypeus forming a right angle on vertex, contiguous to pronotum; seen from side, the eyes are rounded in front, subtruncate posteriorly; seen from below, buccula prominent, pilose, gula noticeably concave, transversally striate. Rostrum reaching middle coxae, first segment very short, not reaching beyond level of antennal peduncle, remaining segments subequal in length.

Antennae inserted in front of eyes, very short, finely pilose; segment I thicker than the others; segment II slender at base, incrassate towards the apex; segments III and IV very slender.

Pronotum strongly declivous, punctate, calli large, occupying the anterior two-thirds of pronotum, surrounded by a furrow with a well marked series of punctures, collar thicker than diameter of first antennal segment, lateral margins carinate and reflexed anteriorly, 
posterior margin straight; mesoscutum exposed, vertically inclined; scutellum small, acute apically, with an excavated depression basally.

Hemielytra with a very wide embolium, distinctly laminate basally, cuneus large, rounded externally, about as long as wide at base, cuneal fracture long and distinct; a well marked row of punctures visible on claval and costal veins, as well as on scutello-claval commissure of scutellar side; radial vein well delineated; membrane very small, uniareolate, coriaceous.

Legs fairly short, tarsi long and slender; segments in order of length: III, I, II; claws toothed at base, of the Deraeocorinae type.

Type of genus: Termatophylella fulvioides, new species.

This genus differs from the other of the Termatophylini, especially from Termatophyloides, in the coriaceous membrane, the well-marked rows of punctures on the hemielytra, in the very short pubescence, and in the large pronotal calli which recall those of the genus Fulvius Stäl.

\section{Termatophylella fulvioides, new species}

Figure 123, $c, f$; Plate 31,B

Characterized by its color and male genitalia.

Male: Length $2.6 \mathrm{~mm}$., width $1.3 \mathrm{~mm}$. Head length $0.3 \mathrm{~mm}$., width $0.5 \mathrm{~mm}$., vertex $0.27 \mathrm{~mm}$. Antennae segment I length 0.1 mm.; II, $0.3 \mathrm{~mm}$.; III, $0.2 \mathrm{~mm}$. IV, $0.2 \mathrm{~mm}$. Pronotum length 0.5 mm., width at base $0.9 \mathrm{~mm}$. Rostrum length $0.8 \mathrm{~mm}$; segment I length $0.20 \mathrm{~mm}$; II, $0.25 \mathrm{~mm}$; III, $0.21 \mathrm{~mm}$; IV, $0.21 \mathrm{~mm}$.

Color: Castaneous (female) or dark castaneous (male). Female with head, pronotum, and scutellum darker; eyes reddish; membrane castaneous with yellowish tinge; antennae pale castaneous; underside castaneous; rostrum, tibiae, and tarsi tending to yellow. Male with eyes reddish; antennae pale castaneous becoming lighter toward the apex; legs reddish castaneous; tibiae and tarsi tending to pale castaneous; rostrum pale.

Morphological characters: As given for the genus.

Genitalia: Left clasper and pygophore as seen in figure 123,c.

Female: Identical to male in morphology and size.

Holotype: Male, San Luis Potosí, México, "Bt. Tex. 69391," on orchids, Mar. 7, 1950, USNM 61947. Allotype: Female, same data as type.

The name of this species is derived from its resemblance to Fulvius Stäl (Cylapinae, Fulviini). 

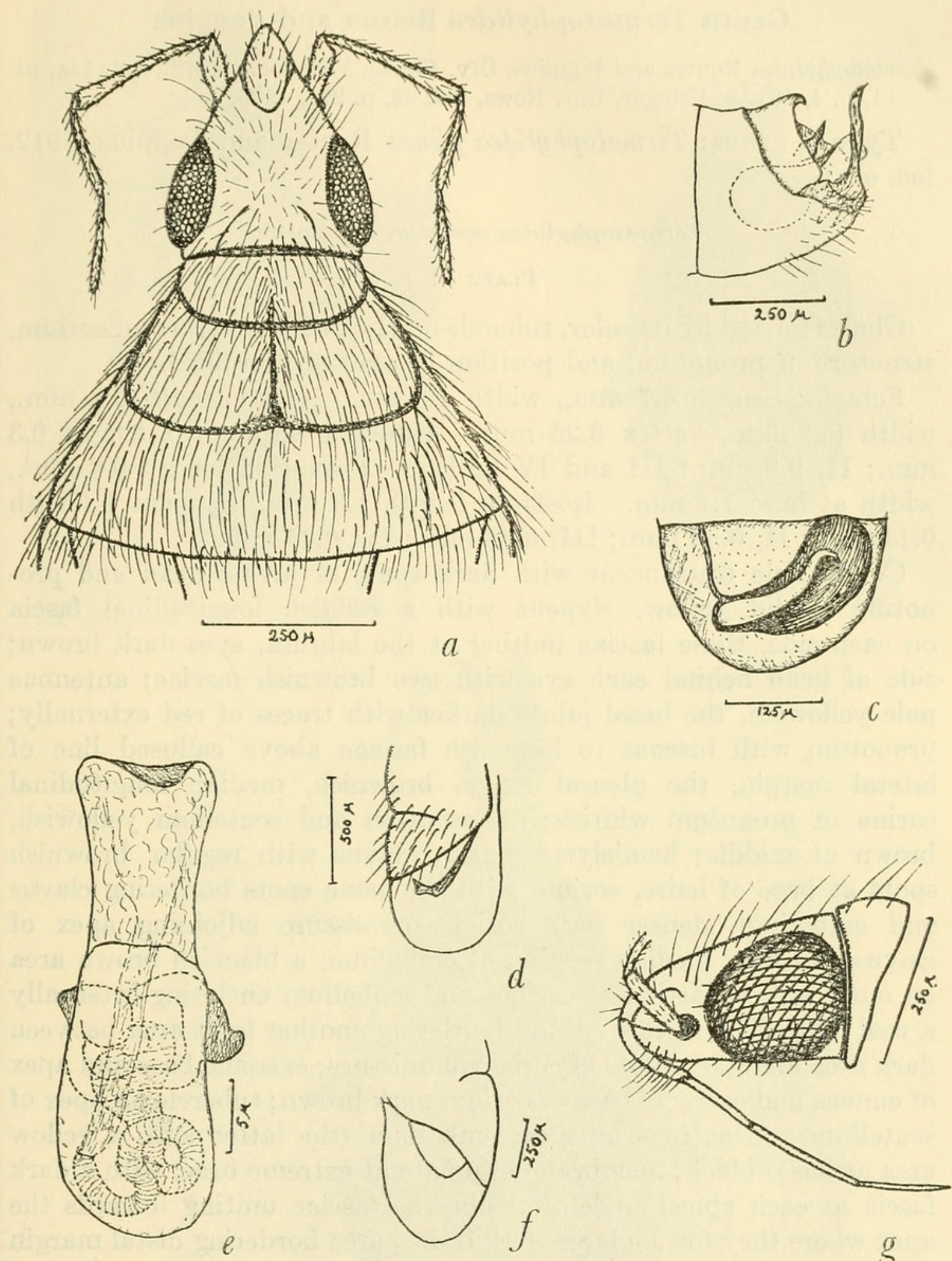

g

Figure 123,- $a$, Head, pronotum, and antennae of Termatophyloides pilosulus, new species; $b$, pygophore of Termatophylidea pilosa Reuter and Poppius; $c$, pygophore of Termatophylella fulvioides, new species; $d$, cuneus and membrane of Termatophyloides pilosulus, new species; $e$, aedeagus of Termatophylidea pilosa Reuter and Poppius; $f$, membrane of Termatophylella fulvioides, new species; $g$, head, side view, of Termatophyloides pilosulus, new species. 


\section{Genus Termatophylidea Reuter and Poppius}

Termatophylidea Reuter and Poppius, Öfv. Finska Vet.-Soc. Förh., vol. 54A, pt. 1, p. 4, 1912.-Usinger, Ent. News, vol. 46, p. 271, 1935.

Type of genus: Termatophylidea pilosa Reuter and Poppius (1912, loc. cit.).

\section{Termatophylidea ocellata, new species}

Plate 31, c

Characterized by its color, tubercle on apex of scutellum and corium, structure of pronotum, and position of eyes on the head.

Female: Length $4.7 \mathrm{~mm}$., width $1.6 \mathrm{~mm}$. Head length $0.8 \mathrm{~mm}$., width $0.6 \mathrm{~mm}$., vertex $0.26 \mathrm{~mm}$. Antennae segment I length 0.3 mm.; II, $0.8 \mathrm{~mm}$.; III and IV broken. Pronotum length $0.8 \mathrm{~mm}$., width at base $1.1 \mathrm{~mm}$. Rostrum length $1.3 \mathrm{~mm}$., segment I length $0.14 \mathrm{~mm}$.; II, $0.53 \mathrm{~mm}$.; III, $0.28 \mathrm{~mm}$.; IV, $0.35 \mathrm{~mm}$.

Color: Pale translucent with dark spots or areas; head and pronotum sordid yellow, clypeus with a reddish longitudinal fascia on each side, these fasciae uniting at the labrum, eyes dark brown; side of head behind each eye with two brownish fasciae; antennae pale yellowish, the basal joints darker with traces of red externally; pronotum with fuscous to brownish fasciae above callused line of lateral margin, the pleural region brownish, median longitudinal carina of pronotum whitish; mesoscutum and scutellum yellowish, brown at middle; hemielytra glassy, clavus with regular brownish spots at base of hairs, corium with the same spots bordering clavus and embolium, denser near corial commissure adjoining apex of clavus and near median portion of embolium, a blackish brown area on outer apical portion of corium and embolium enclosing internally a well marked hyaline spot and bordering another light area between dark area and dark spots of corial commissure; extreme base and apex of cuneus and extreme base of corium dark brown; tubercle on apex of scutellum and extreme apex of embolium (the latter with a yellow area at base) black; membrane infumate at extreme base, with a dark fascia at each apical angle of areola, the fasciae uniting towards the apex where they form a large dark brown area bordering distal margin of membrane; transversal apical portion of vein areola red; legs and abdomen pale yellow, the latter with a lateral fascia showing some darker areas, claws brown.

Head strongly pointed, vertex with a $V$-shaped depression level with posterior margin of eyes, carinate; eyes large, touching the gula below, distant from collar by a space equal to half the length of eye or half the length of first antennal segment; rostrum reaching the 

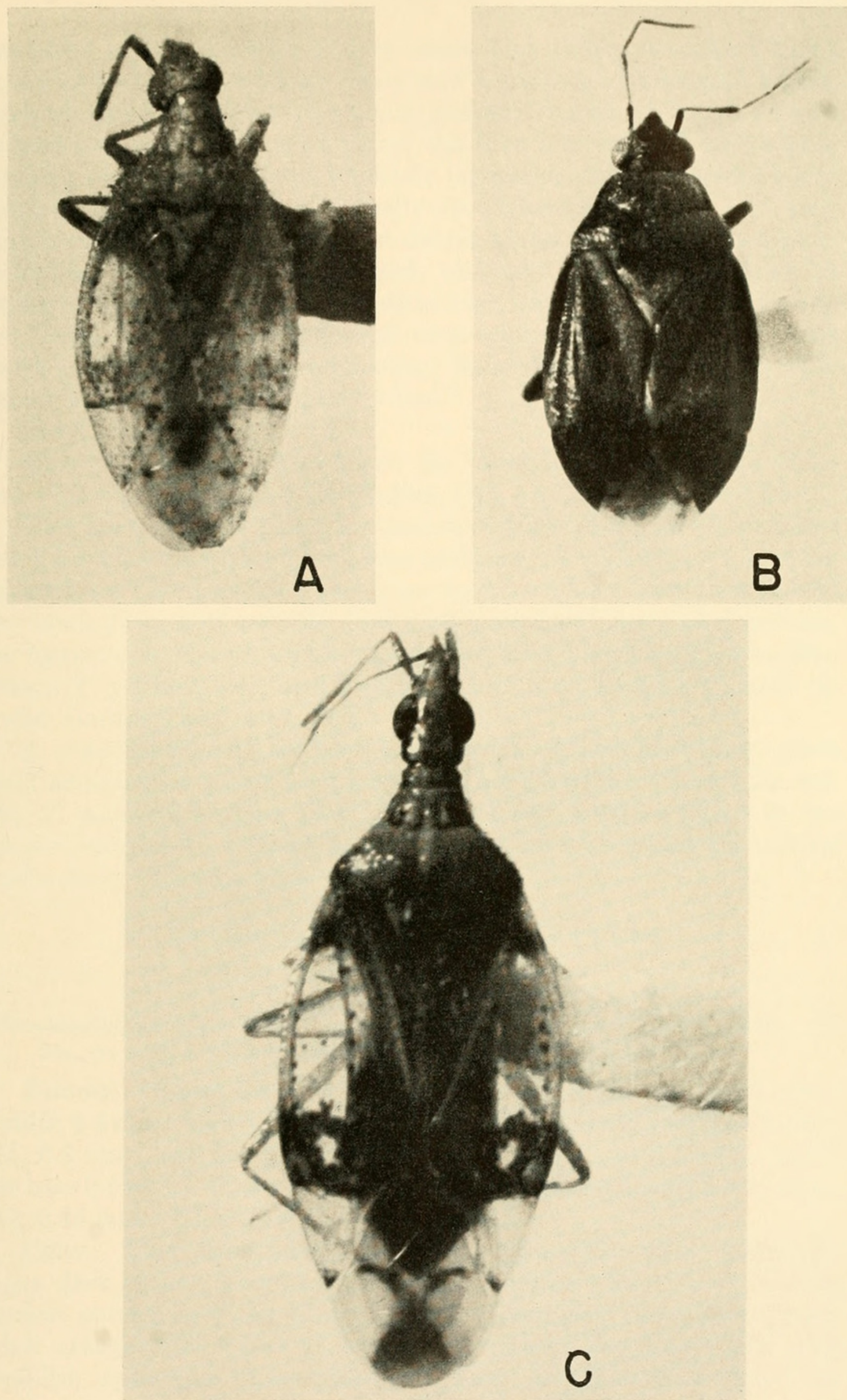

A, Termatophylidea opaca, new species; B. Termatophylella fulvioides, new species; C, Termatophylidea ocellata, new species. 
$x+2$ 
anterior coxae, segment I very short and thick; pronotum finely punctate with longitudinal crests and a median longitudinal carina, calli reaching the sides of pronotum, posterior margin of disc biconcave; scutellum and mesoscutum hairy, the first convex, with acute apex ending by a characteristic, minutely pubescent, black tubercle; hemielytra with claval area internally to claval vein raised and very minutely pilose, this pubescence denser along claval vein, embolium wide and incrassate with a raised, minutely pubescent tubercle at apex; cuneus about as long as wide at base, distinctly curved internally on basal two thirds; membrane very minutely pilose (visible only with good illumination), uniareolate; body beset with very long, fine, erect setae, the eyes distinctly pilose.

Male: Unknown.

Holotype: Female, San Pedro de Montes de Oca, Costa Rica, on Vernonia brachiata, C. H. Ballou, Oct. 15, 1936; USNM 61948.

This species differs from T. maculata Usinger, 1935, in the presence of a tubercle on apex of scutellum and apex of embolium, in color of hemielytra (in maculata there is no ocellate hyaline spot surrounded by black at apex of corium), in the less prominent crests of pronotum, in larger eyes, and in greater separation of eyes from pronotal collar. From T. pilosa Reuter and Poppius, 1912, it is readily separated by color markings and larger size.

A redescription of Reuter and Poppius' T. pilosa is here given and attention is called to the illustrations given for this species and for T. maculata Usinger (Ent. News, vol. 46, p. 271, 1935). In the paper referred to, Usinger describes maculata and points out critical differences between these two species.

\section{Termatophylidea pilosa Reuter and Poppius}

Figure 123,b,e

Termatophylidea pilosa Reuter and Poppius, Öfv. Finska Vet.-Soc. Förh., vol. 54A, pt. 1, p. 4, 1912.-Usinger, Ent. News, vol. 46, p. 271, 1935.

Female: Length $3.8 \mathrm{~mm}$., width $1.3 \mathrm{~mm}$. Head length $0.7 \mathrm{~mm}$., width $0.4 \mathrm{~mm}$., vertex $0.17 \mathrm{~mm}$. Antennae segment I length $0.3 \mathrm{~mm}$.; II, $0.8 \mathrm{~mm}$.; III and IV broken. Pronotum length $0.7 \mathrm{~mm}$., width at base $0.9 \mathrm{~mm}$. Rostrum length $1.2 \mathrm{~mm}$.; segment I length $0.11 \mathrm{~mm}$; II, $0.45 \mathrm{~mm}$.; III, $0.28 \mathrm{~mm}$; IV, $0.40 \mathrm{~mm}$.

Color: Pale translucent, head and pronotum dirty yellowish; eyes dark brown, sides of head behind each eye with a brown fascia, apical portion in front of clypeal suture and first antennal segment dull orange with traces of red, second antennal segment pale with reddish apex and base; pronotum dirty yellow with a brown to 


\section{$2 \mathrm{BHL}$ Biodiversity Heritage Library}

Carvalho, José Cândido de Melo. 1955. "Neotropical Miridae, LXV: New genera and species of bugs of the tribe Termatophylini (Hemiptera: Deraeocorinae)." Proceedings of the United States National Museum 104(3348), 641-649.

https://doi.org/10.5479/si.00963801.104-3348.641.

View This Item Online: https://www.biodiversitylibrary.org/item/52773

DOI: https://doi.org/10.5479/si.00963801.104-3348.641

Permalink: https://www.biodiversitylibrary.org/partpdf/51042

\section{Holding Institution}

Smithsonian Libraries

\section{Sponsored by}

Smithsonian

\section{Copyright \& Reuse}

Copyright Status: Public domain. The BHL considers that this work is no longer under copyright protection.

This document was created from content at the Biodiversity Heritage Library, the world's largest open access digital library for biodiversity literature and archives. Visit BHL at https://www.biodiversitylibrary.org. 